\title{
Erosion rates and sediment yields of glaciers
}

\author{
JIM BOGEN \\ Norwegian Water Resources and Energy Administration, P.O. Box 5091, Maj. 0301, Oslo, Norway
}

\begin{abstract}
Sediment yields and glacial erosion rates are evaluated for four Norwegian glaciers during the years 1989-93. Annual erosion rates were determined from measurements of sediment load and water discharge in glacial meltwater rivers. The mean sediment yield and the corresponding erosion rate of the valley glaciers Engabreen and Nigardsbreen were found to be $456 \mathrm{t} \mathrm{km}^{-2}$ year ${ }^{-1}\left(0.168 \mathrm{~mm}^{-1}\right.$ year $\left.^{-1}\right)$ and $210 \mathrm{t} \mathrm{km}^{-2}$ year $^{-1}\left(0.078 \mathrm{~mm}^{-1}\right.$ year $\left.{ }^{-1}\right)$, respectively. A small and slow-moving cirque glacier Ovre Beiarbre yielded a rate of $482 \mathrm{t} \mathrm{km}^{-2}$ year ${ }^{-1}\left(0.178 \mathrm{~mm}^{-1} \mathrm{ear}^{-1}\right)$, and the sub-polar Svalbard glacier Broggerbreen yielded $613 \mathrm{t} \mathrm{km}^{2}$ year $^{1}\left(0.226 \mathrm{~mm}^{-}\right.$year $\left.{ }^{-1}\right)$. The erosion rates are low compared to glaciers elsewhere. There are also considerable variations in sediment yields at each glacier from year to year. However, different factors are found to control the variability on each individual glacier. Analysis of the relationship between water discharge and sediment concentration in meltwater rivers suggests that changes in subglacial drainage systems cause variations in sediment availability and the way sediments are melted out from the ice. When water pressure drops, the drainage system in fast-moving, thick valley glaciers deforms at a more rapid rate than in thin, slow-moving ones. New volumes of debris-laden ice are thus more readily available for melting when water pressure next increases. Beneath the thin, slow-moving Ovre Beiarbre, single years with high transport rates and evacuation of sediment are followed by periods of low availability lasting for 2 years or longer. It is suggested that this pattern results from exhaustion of sediment in a stable drainage system, with more sediment becoming available when the position of the subglacial drainage system is changed.
\end{abstract}

\section{INTRODUCTION}

Sediment yield, based on a monitoring programme of sediment transport in meltwater rivers, is often used to obtain the rate of erosion beneath a glacier. Such measurements in a number of glacier rivers in different regions have shown that suspended-sediment concentration in meltwater is highly variable at both short-term and seasonal time-scales. This variability has been related to availability of sediment supplied to the subglacial channel system (Ostrem, 1975), changes in the area that water is washing over during a flood event (Liestøl, 1967) and exhaustion effects (Gurnell, 1987; Gurnell and others, 1994). Collins (1989) interprets the seasonal pattern of variation in sediment flux of meltwater from Gornergletscher as a seasonal development of the subglacial drainage system. Throughout the season, areas of previously hydraulically isolated sub-sole are integrated with flow, releasing quantities of sediment from basal storage.

Sediment yields have been shown to be different for various types of glaciers. With some exceptions, large valley glaciers are characterized by large yields, and small cirque glaciers by low yields. Glaciers in different regions having different thermal regimes and on various bedrock types are also characterized by different yields (Hallet and others, 1996).
Annual sediment yields of Norwegian glaciers (maximum $1300 \mathrm{t} \mathrm{km}^{2}$ ) are, in general, lower than those of glaciers elsewhere. The sediment yield at Vatnajökull has been measured as $12 \mathrm{kt} \mathrm{km}^{-2}$ (Tomasson, 1987) and at Gornergletscher as $6 \mathrm{kt} \mathrm{km}^{2}$ (Bezinge, 1978). When the glacial erosion rate is high, a different pattern of sediment flux is expected from that produced by glaciers with small rates. Sediment yields of Norwegian glaciers are subject to variations from year to year. In some cases such variations may be of the same order as those between different glaciers. Glacial erosion is dependent on glacial quarrying and abrasion, processes that are unlikely to vary on timescales shorter than decades. Thus, year-to-year variability in sediment yield has to be accounted for by other processes. This paper presents sediment yields for four glaciers in Norway and discusses reasons for the annual variations. Sediment yields are then translated into erosion rates.

Sediment yields are obtained by monitoring of water discharge and sediment transport in meltwater streams close to glacier outlets. Sediment samples were collected with ISCO automatic samplers programmed for four samples a day. Grain-size analyses of the suspendedsediment load were determined on large-volume samples collected on a weekly basis. Further descriptions of the methods are given by Bogen (1986, 1988 , $1992)$. 


\section{SEDIMENT YIELDS}

The glaciers studied are shown in Figure 1. Ovre Beiarbre is a small cirque glacier $\left(2.4 \mathrm{~km}^{2}\right.$; see Table 1$)$, situated in northern Norway, east of the Svartisen ice cap. Sediment transport has been monitored in its meltwater river since 1988. The sediment yield in 1988 was one of the highest on record among Norwegian glaciers at that time. The rate of $886 \mathrm{t} \mathrm{km}^{2}$ year ${ }^{-1}$ has only been exceeded at nearby Trollbergdalsbreen (Ostrem, 1975). The high yield did not last, and suspended-sediment delivery declined to $176 \mathrm{t} \mathrm{km}^{-2}$ year $^{-1}$ in 1989 , and $173 \mathrm{t} \mathrm{km}^{2}$ year $^{-1}$ in 1990. In 1991, however, the sediment yield exceeded the 1988 level, reaching $1136 \mathrm{t} \mathrm{km}^{-2}$ year $^{-1}$ before falling to lower levels in 1992 and 1993 (Fig. 2). Thus, high year-to-year variability appears to be a characteristic feature of the sediment transport in the Beiarbreen meltwater river. As seen from the record of water discharge, the high yields are due to higher concentrations of sediments and not to larger runoff in these years.

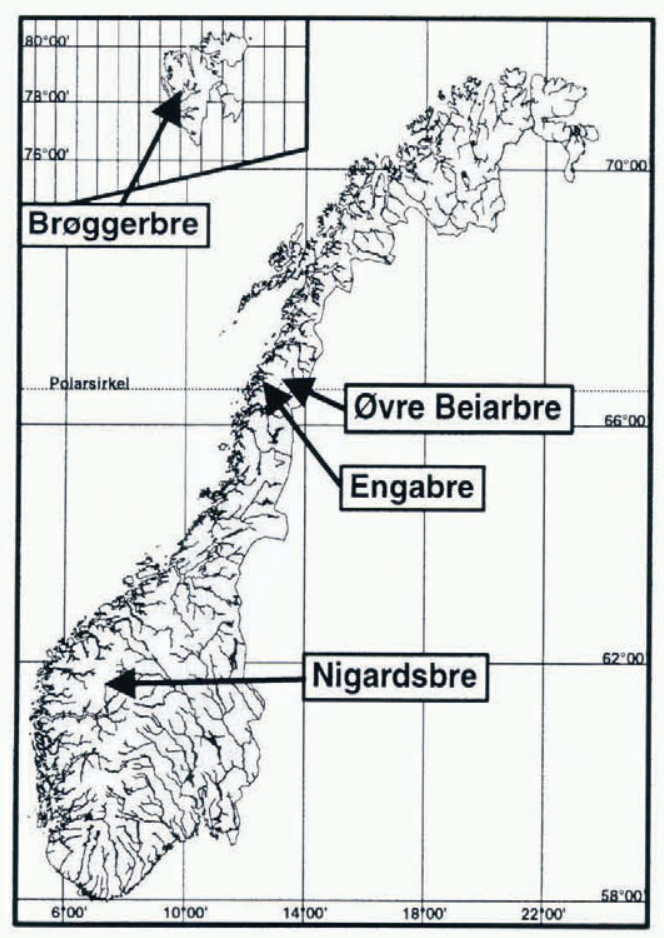

Fig. 1. Location of glaciers in Norway included in this study.

Table 1. Area, mean sediment yield and mean erosion rates of the investigated glaciers

\begin{tabular}{lrcc} 
Glacier & Area & $\begin{array}{c}\text { Mean sediment } \\
\text { yield } \\
\mathrm{km}^{2} \mathrm{~km}^{2} \text { year }^{-1}\end{array}$ & $\begin{array}{c}\text { Mean erosion } \\
\text { rate } \\
\text { mm year }\end{array}$ \\
\hline $\begin{array}{l}{ }^{-1} \\
\text { re Beiarbreen }\end{array}$ & 2.4 & 482 & 0.178 \\
$\begin{array}{l}\text { ardsbreen } \\
\text { gabreen }\end{array}$ & 48.2 & 211 & 0.078 \\
gabren & 36.2 & 613 & 0.226 \\
& 456 & 0.168
\end{tabular}

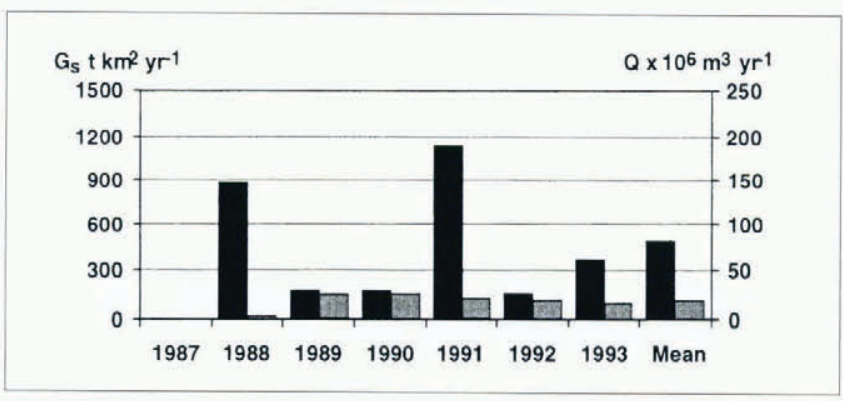

Fig. 2. Annual sediment yield, $\mathrm{g}_{s}$, (solid columns) and runoff, Q, (grey) from Ovre Beiarbre during the years 1988-93.

It is difficult to relate the high yields to glaciological variables. The glacier is thin and slow-moving, and is apparently unable to erode these high rates in its present state. For this reason, Ostrem (1975) attributed the high yields of Trollbergdalsbreen to supply from sediments eroded during a former, more active phase. To illustrate further the sudden change in sediment concentration, a regression analysis of concentration vs water discharge was carried out for a year of high yields (1991) and one of low yields (1990). Significant correlations were found for each year (Fig. 3). However, an analysis of the combined data for both years resulted in a lower coefficient of correlation, indicating two different populations. This phenomenon may be due to a shift in sediment sources, possibly caused by a change in the position of the subglacial conduits.

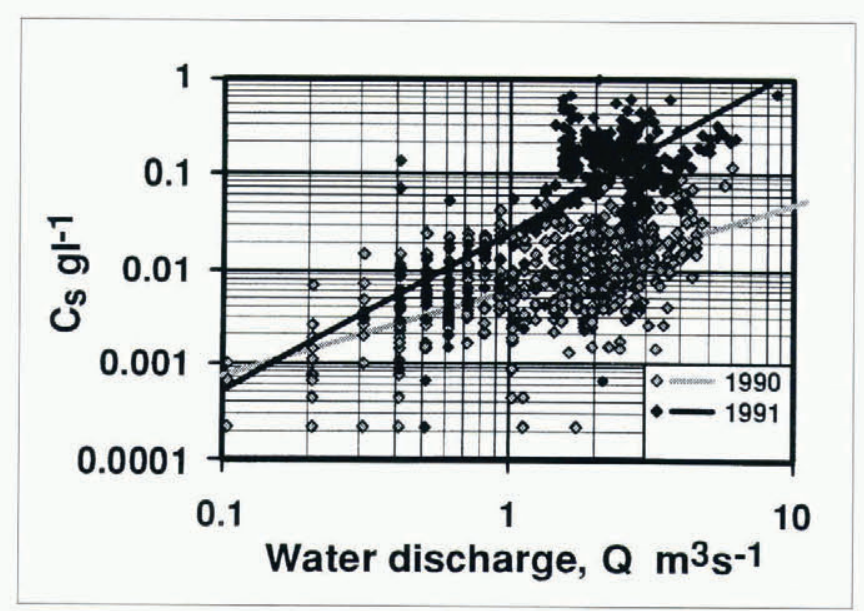

Fig. 3. Regression analysis of suspended-sediment concentration, $\mathrm{C}_{\mathrm{s}}$ is discharge, $\mathrm{Q}$, in the meltwater river from Oore Beiarbre. Coefficient of correlation on data from 1990, $r=0.67$ and 1991, $r=0.73$. An analysis including both years gave $r=0.36$.

The valley glacier Nigardsbreen $\left(48.2 \mathrm{~km}^{2}\right)$, an outlet from the Jostedalsbre ice cap, shows a similar variability. The year-to-year variations are not as large as for Ovre Beiarbre. However, there is no significant correlation between water discharge and sediment concentration on an annual basis (Figs 4 and 5 ). In addition, the range of concentration is narrower than at Ovre Beiarbre, and no concentrations lower than $0.010 \mathrm{gl}^{-1}$ were observed. 


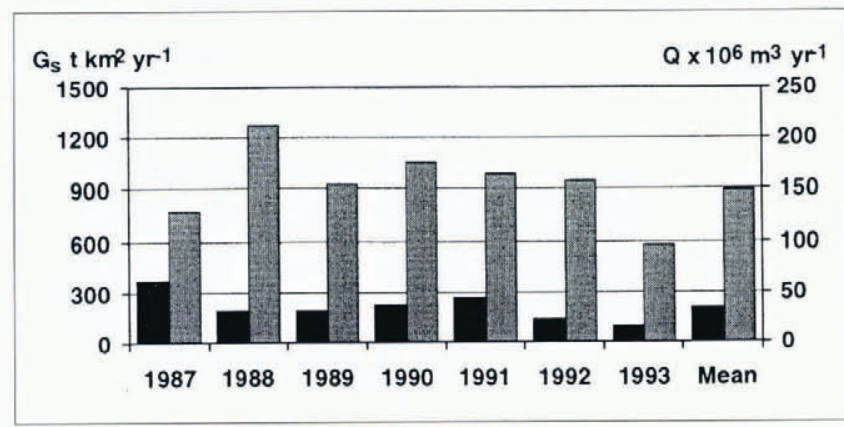

Fig. 4. Annual sediment yield, $\mathrm{g}_{\mathrm{s}}$, (solid columns) and runoff, Q, (grey) of Nigardsbreen during the years 1987 93.

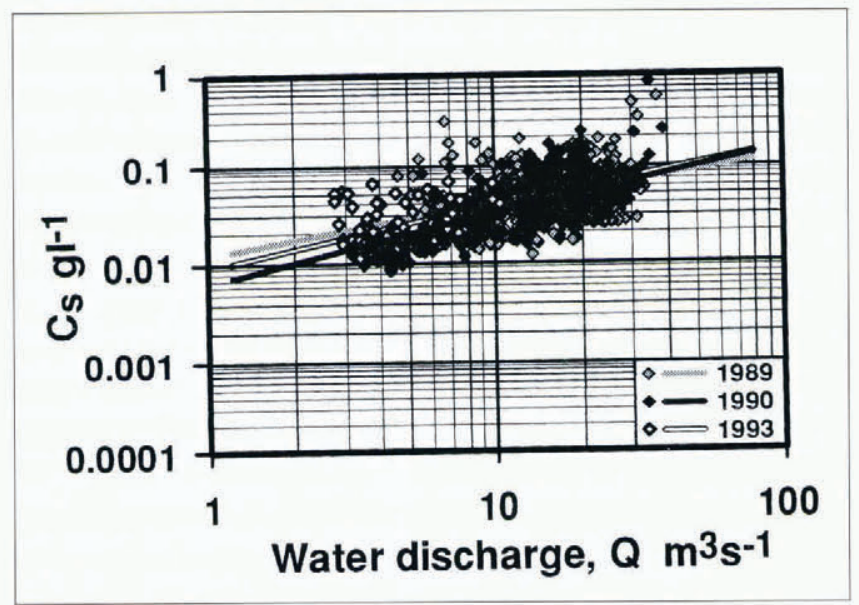

Fig. 5. Regression analysis of suspended-sediment concentration, $\mathrm{C}_{\mathrm{S}}$ us water discharge, $\mathrm{Q}$, in the meltwater river from Nigardsbreen. Coefficients of correlation of the three years 1989, 1990 and 1993 are $r=0.36,0.56$ and 0.70 , respectively. Analysis of all years together gives $r=0.55$.

A similar pattern is observed at Engabreen (36.2 $\mathrm{km}^{2}$ ), a western outlet glacier of the Svartisen ice cap (Fig. 6). The correlations were as low as 0.30 in 1990 , when the yield was high, increasing to 0.6 in 1992, a year of lower yield (Fig. 6).

The pattern of variability in sediment yield for these glaciers may be interpreted in terms of a model where the sediments are introduced to the subglacial waterways by

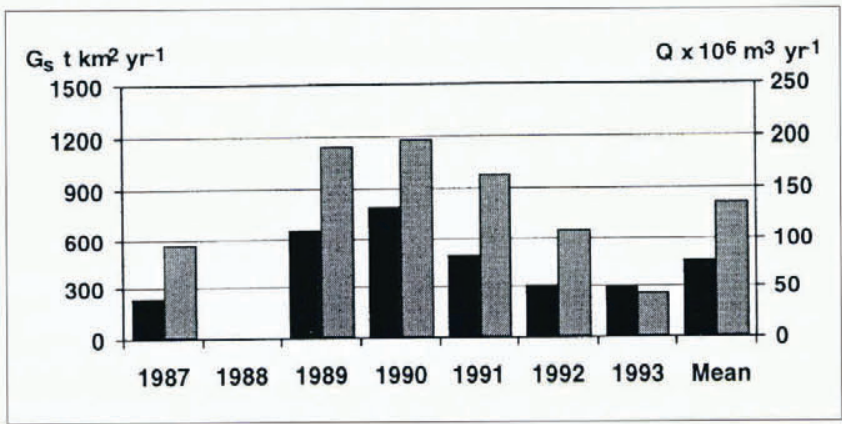

Fig. 6. Annual sediment yield, $\mathrm{g}_{\mathrm{s}}$, (solid columns) and runoff, Q, (grey) from Engabreen during the years 1.98793. No measurements were made in 1988. melting of debris-rich ice in the glacier sole (Fig. 7). The rate of deformation of conduits depends on the difference between the ice overburden pressure and the internal water pressure. Due to variations in glacier melting and precipitation, water discharge in the subglacial conduits is subject to changes throughout the season. In periods of low water discharge, the movement of the glacier and the plastic deformation of the ice will deform the conduits. A subsequent expansion by an increase in water pressure will melt more ice and add more sediments to the subglacial system. In a system of equilibrium conduits, the dominant sediment sources are the beds of the conduits and possible subglacial till. Such sources should be expected to give a good relation between sediment load and discharge, but that is not true for the glaciers included in this study. The pattern of sediment transport in the meltwater rivers of the glaciers is availabilitycontrolled. That is, the rate of increase in discharge does not always give the same rate of increase in sediment load, depending on whether sediments are available for transport. This pattern, along with the low erosion rate, strongly suggests that subglacial till is not the dominant source. Most probably, the glacier soles are resting on bedrock on which till is only present in patches. In such systems, fluctuations in water pressure and glacier flow rate are as important as total runoff in controlling the acquisition of sediment.

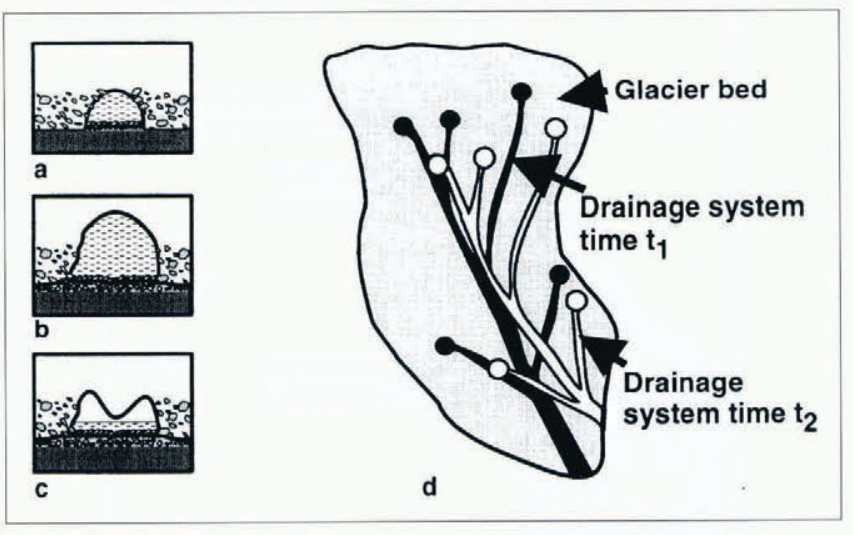

Fig. 7. Schematic diagram indicating the way that a cavity or an ice tunnel melts out sediments incorporated in the ice. $(a, b)$ Water pressure is rising and the subglacial cavity is expanding. (c) Water pressure is falling and the tunnel or cavity is deformed. (d) Changes in the position of the drainage system may increase availability of sediments.

It is likely that thick, fast-moving glaciers such as Nigardsbreen and Engabreen will deform their empty subglacial conduits at a more rapid rate than the thin, slow-moving Ovre Beiarbre. Water from the subglacial conduits of Engabreen is used for hydroelectric purposes, and water is collected beneath the glacier. Engabreen is $200 \mathrm{~m}$ thick in the area of the subglacial water intake. Inspection tunnels melted out beneath the ice are subject to substantial deformation in the course of 3-4 days. The poor correlation between water discharge and sediment concentration suggests that such deformation of the conduits takes place continously throughout the season. This process is more rapid at Engabreen than at Ovre 
Beiarbre. At the water intake, the lowest part of the ice consists of a debris-rich sole 1-2 $\mathrm{m}$ thick, moving over a mostly bare rock bed. The bedrock areas are no source of sediments for the subglacial waterways. However, pockets of subglacial till may exist outside the investigated areas.

Channels do not necessarily form in the same position each year. There are several intakes beneath Engabreen, and the position of the active intake shifted between 1993 and 1994. The somewhat larger yearly variability of the Engabreen record compared to Nigardsbreen may be attributed to more frequent shifts in channel positions to areas that may have different concentrations of debris in basal ice.

Beneath the thin, slow-moving Ovre Beiarbre, conduits do not deform at the same rate as beneath the two other glaciers. The basal ice along the subglacial drainage system may after some time be washed clear of sediments. Deformation of the conduits to allow for more melting of debris-laden ice will take a longer time. In some years, there is a large shift in sediment yield, but such a shift does not necessarily take place every year. Most probably, a year with high yield is preceded by a winter deformation causing a major change in the position of the conduits or linked-cavity systems to areas of ice richer in sediment. In some years the sediment yield remains low, presumably because no change in position took place.

Broggerbreen is a sub-polar glacier, located near $\mathrm{Ny}$ Alesund in Svalbard. Year-to-year variability in sediment yield is high, as shown in Figure 8. Sediment loads have been found to be correlated with water discharge (Repp, 1978, 1985; Bogen, 1989, 1991), but in recent years this correlation has been weak.

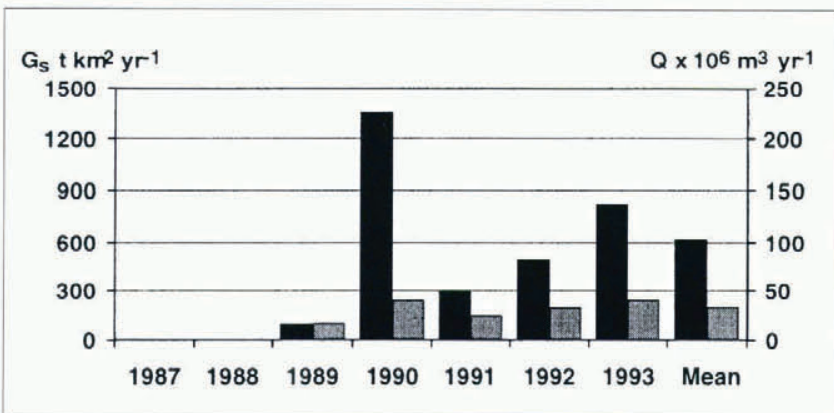

Fig. 8. Annual sediment yield, $\mathrm{g}_{\mathrm{s}}$, (solid columns) and runoff, Q, (grey) of Broggerbreen 198993.

The sediment-monitoring station is situated about $1 \mathrm{~km}$ downstream from the glacier snout. Some erosion of moraine material and formerly deposited sediments along river-banks takes place. Thus, the sediment yield may also be influenced by processes in the proglacial reach of the channel.

\section{DISGUSSION AND CONGLUSIONS}

The pattern of yearly variability of erosion rates indicated by sediment yields is different for the four glaciers included in this study. The small, thin Ovre Beiarbre is characterized by years of excessively high sediment yield being interspersed with low-yield periods of at least 2 years. It is suggested that this pattern is associated with sediment-exhaustion effects that last for some years, followed by channel changes that increase sediment availability.

The relatively thick and fast-moving valley glaciers Engabreen and Nigardsbreen seem to maintain sediment availability by deformation of their subglacial conduits and subsequent melt-out of sediments when the water level rises again. Much sediment is washed out from these glaciers in summers when water pressure is subject to frequent fluctuations.

The dependency of sediment yield on water discharge for the sub-polar Broggerbreen during some years indicates a system of conduits that rarely change their position from year to year. However, in other years channel changes may take place, making more sediment available. A significant part of the sediment load may be eroded from subaerial locations.

Glacial quarrying and abrasion convey a continuous supply of debris to the glacier sole. The sediment yield of glaciers is dependent on the concentration of debris at the sole and, at least for the temperate glaciers included in this study, there is a clear relation to glacial erosion rate.

However, the melt-out processes that remove debris from the sole operate on a much shorter time-scale than glacier erosion. In order to use records of sediment yield in meltwater to estimate erosion rates, several years of data should be used to even out variability originating from melt-out processes. Average values are then the most meaningful indicators of long-term bedrock erosion rates (Table 1).

It is interesting to compare the present rate of erosion of Engabreen $\left(0.168 \mathrm{~mm}\right.$ year $\left.^{-1}\right)$ with the rate obtained by Rekstad (1912). Rekstad estimated a rate of $11 \mathrm{~mm}$ year $^{-1}$ from the infill of a small lake in front of the glacier. At that time, the snout of the glacier most probably rested on old lake sediments deposited in lake Engabrevatn prior to the glacier advance of the 18th century. Despite the difference in methods, it may be concluded that glacial erosion of a soft bed beneath this glacier takes place at a rate that is at least one order of magnitude larger than that of bedrock.

\section{ACKNOWLEDGEMENTS}

This work is a part of the research project "Processes of erosion and sediment transport" funded by the research and development programme of the Norwegian Water Resources and Energy Administration. J. Kohler, R. Motyka and the editors P. Holmlund and D. Collins read an early version of this paper and gave valuable comments.

\section{REFERENGES}

Bezinge, A. 1978. Torrents glaciaires, hydrologic et carriages d'alluvions. Jahrbuch der Schweizerischen. Valurforschenden Gesellschaft 1978, 152-169. Bogen, J. 1986. Transport of suspended sediment in streams. In Hasholt. B., ed. Partikulert bundet stofftransport i vand og jorderosjon. The Coordination Committee for Hydrology in the Nordic Countries 
KOHYNO). Nordic Hydrological Programme, 9-21. (NHP Report 14.

Bogen, J. 1988. A monitoring programme of sediment transport in Norwegian rivers. International Association of Hydrological Sciences Publication 174 (Symposium at Porto Alegre, Brazil 1988 - Sediment Budgets ), 149-159.

Bogen, J. 1989. Glacial sediment production and development of hydroelectric power in glacierized areas. Ann. Glaciol, 13, 6-11.

Bogen, J. 1991. Erosion and sediment transport in Svalbard. In Gjessing, Y., J. O. Hagen, K. A. Hassel, K. Sand and B. Wold, eds. Arctic hydrology: present and future tasks. Hydrology of Sualbard - hydrological problems in a cold climate. Oslo, Norwegian National Committec for Hydrology, 147-158. (Report 23.

Bogen, J. 1992. Monitoring grain size of suspended sediments in rivers. International Association of Hydrological Sciences Publication 210 (Symposium at Oslo 1992 - Erosion and Sediment Transport Monitoring Programmes in River Basins), $183-190$.

Collins, D. N. 1989. Seasonal development of subglacial drainage and suspended sediment delivery to melt waters beneath an Alpine glacier. Ann. Glaciol., 13, 45-50.

Gurnell, A. M. 1987. Suspended sediment. In Gurnell, A. M. and M.J. Clark, eds. Glacio-fluvial sediment transfer: an alpine perspective. Chichester, etc., John Wiley and Sons, 305-354.

Gurnell, A. M., A. Hodson, M.J. Clark, J. Bogen, J. O. Hagen and M.
Tranter. 1994. Water and sediment discharge from glacier basins: an Arctic and Alpine comparison. International Association of Hydrological Sciences Publication 224 Symposium at Canberra 1994 - Variability in Stream Erosion and Sediment Transport), $325-334$.

Hallet, B., L. E. Hunter and J. Bogen. 1996. Rates of erosion and sediment evacuation by glaciers: a review of the evidence. Global and Planetary Change, 12, 213-235.

Liestol, O. 1967. Storbreen glacier in Jotunheimen, Norway. Nor. Polarinst. Skr. 141.

Ostrem, G. 1975. Sediment transport in glacial meltwater streams. In Jopling, A. V. and B. C. McDonald, eds. Glaciofluvial and glaciolacustrine sedimentation. Tulsa, OK, Society of Economic Paleontologists and Mineralogists, 101-122. (SEPM Special Publication 23.

Rekstad, J. 1912. Die Ausfüllung eines Sees vor dem Engabre, dem grössten Ausläufer des Svartisen, als Mass der Gletschererosion. Z. Gletscherkd., 6, 212-214.

Repp, K. 1978. Breerosjon, glaci-hydrologi og materialtransport i et hoyarktisk miljo. Broggerbreene, vest Spitsbergen. Ph.D. thesis, University of Oslo.

Repp, K. 1988. The hydrology of Bayelva, Spitsbergen. Nord. Hydrol., 19 (4), 259-268.

Tómasson, H. 1986. Glacial and volcanic shore interaction. Part 1. On land. In Sigbjarnarson, G., ed. Proceedings, Iceland Coastal and River Symposium. Reykjavik, National Energy Authority, 7-16. 